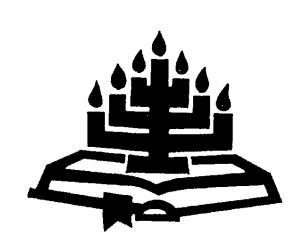

\title{
Geloofsvolwassenheid en Christelike spiritualiteit binne die knyptang van prestasiedruk tydens vroegbejaardheid
}

\author{
D.J. (Daniël) Louw \\ Departement Praktiese Teologie en Missiologie \\ Universiteit van Stellenbosch \\ STELLENBOSCH \\ E-pos: djl@sun.ac.za
}

\begin{abstract}
Spiritual maturity and Christian spirituality within the crush between performance pressure and adjustment to early pre-elderliness

In this article it is argued that a developmental understanding of the different stages of life is appropriate for a pastoral hermeneutical approach. In order to link spiritual maturity to life issues, both J. Fowler's and E.H. Erikson's developmental models are discussed. However, little attention has been given in existing subject-related research to the "in-between stage": between performance and preparation for retirement. In order to focus a pastoral hermeneutics on the unique needs this phase has for Christian spirituality, it is argued that an understanding of the Biblical notion of parrhēsia can play a decisive role in helping people to discover continuity and courage "to be in order" and to cope with the eventual demands of old age. For this purpose a new aesthetics should be rediscovered: the existence of the sublime within the ridiculous. (The paradox of hope and beauty despite fraity and disfigurement.)
\end{abstract}

\section{Opsomming}

Geloofsvolwassenheid en Christelike spiritualiteit binne die knyptang van prestasiedruk tydens vroegbejaardheid

'n Ontwikkelingsmodel om die impak van die verskillende lewensiklusse op geloofsvolwassenheid te verstaan is baie belangrik. Ten einde geloof en spiritualiteit toe te spits op lewenstake, word aandag gegee aan die modelle van J. Fowler en E.H. Erikson. Omdat tot dusver in bestaande navorsing oor 
hierdie kwessie min aandag gegee is aan die knyptangfase tussen 50-65 jaar (die tussen-in-fase van prestasiedruk en 'n bewuswording van die broosheid van bejaardheid) word hierdie fase ontleed. Ten einde 'n pastorale hermeneutiek toe te spits op die eise wat hierdie fase aan 'n Christelike spiritualiteit stel, word aangevoer dat die Bybelse konsep parrhēsia kan bydra tot ' $n$ vastigheid, kontinuïteit en moed wat die mens help om die eise van die ouderdom te hanteer. Vir hierdie doel behoort 'n nuwe estetika ontdek te word: die sublieme midde-in die belaglike (die paradoks van skoonheid en hoop te midde van broosheid en fisieke aftakeling).

\section{Inleiding}

Daar is een faset in die teorie oor die ontwikkelingsiklusse van die mens wat dikwels oor die hoof gesien word, naamlik die fase tussen die topkurwe van beroepsuitsette met al die eise daaraan verbonde en die voorbereiding op aftrede en lewensafronding. Hierdie fase kan beskryf word as die fase van afronding en aanpassing wat gekoppel word aan die lewensfase tussen 55 en 65 jaar. ${ }^{1}$ In die psigologie, sosiologie en pastoraat word baie aandag gegee aan die peuterfase, die kleuterfase, die skoolgaande kind, die tiener en adolessensie, vroeë volwassenheid, midde-volwassenheid en laat volwassenheid. Heelwat aandag word bestee aan huweliks- en gesinsverryking. Spiritualiteit is deel van die dringende debat oor die mens se geestelike behoeftes, onder andere die bewussyn van transendensie en die soeke na sin. So byvoorbeeld skryf die pastorale teoloog, D. Tieleman (1995:114) oor die hernude soeke na 'n vorm van Christelike spiritualiteit in 'n gesekulariseerde samelewing: hierdie vorm van spiritualiteit behels 'n soeke na 'n nuwe verstaan van God en humaniteit met die oog op 'n herevaluering van menslike gemeenskaplikheid. Tieleman (1995: 119) pleit dan ook vir 'n dialogiese spiritualiteit waarbinne die steriele onderskeid tussen die sakrale en die sekulêre sal wegval (Tieleman, 1995:123). ${ }^{2}$

1 Vanweë die fokus op vroegbejaardheid val die vraagstuk van die manlike menopouse (ongeveer tussen 45 en 55 jaar) buite die skopus van hierdie artikel. Vergelyk Lotter (2001:175-185) oor die manlike menopouse.

2 Vir 'n bespreking van spiritualiteit, kyk Louw (1999:222-238). Daar bestaan verskillende tipes spiritualiteit. So byvoorbeeld is daar die teosentriese fokuspunt in 'n gereformeerde spiritualiteit (kyk Van't Spijker, 1993:326; vgl ook Velema, 1990:55). In meer resente denke oor spiritualiteit beklemtoon Anderson (2003:1146) die waarde van 'n meer sakramentele benadering tot "spiritual caregiving". Daar is 'n verskuiwing weg van 'n leerstellige verstaan van spiritualiteit (ortodoksie) na 'n "personal engagement" met God (ortopraksie) (kyk Kourie, 
Al hierdie sake is vir die pastorale bediening en ons menswees belangrik. Dit is inderdaad waar dat die vraagstuk van sin en spiritualiteit3 wesenlik aan mekaar gekoppel is. Nêrens word singewing en spiritualiteit egter gedurende die menslike lewensiklusse so getoets, gelouter en in-gekonsertina as in die fase tussen prestasiedruk (performance 4 ) en aftrede nie. Hierdie artikel wil ondersoek instel na wat die aard van die impak van hierdie fase net voor aftrede op geloofsgroei en Christelike spiritualiteit behels. Vandaar die kernvraag van die artikel: wat is die impak van die hedendaagse prestasiedruk op die spiritualiteit van professionele beroepe en watter impak het dit op die sogenoemde piekfase van volwassenheid voor aftrede (tussen 55 en 65 jaar)? Hoe bepaal hierdie fase die uiteindelike fase van bejaardheid (hetsy vroeë, midde- of hoogbejaardheid)?

Met die oog op 'n herevaluering van geloofsvolwassenheid en Christelike spiritualiteit gedurende hierdie knyptang- of konsertinafase, sal eerstens gekyk word na die wisselwerkende verband tussen geloofsontwikkeling en die mens se lewensfases; die eiesoortige eise van die knyptangfase en die uitwerking daarvan op menslike selfverstaan; geloofsvolwassenheid en spiritualiteit; die uitdaging wat so 'n tussenfase - tussen hoog-volwassenheid (die piekkurwe) en vroeë bejaardheid - aan geloofsvolwassenheid stel.

2000:28-29). Vir 'n meer Protestantse benadering, vergelyk Driskill (1999). Vir 'n oorwegend Rooms-Katolieke benadering, kyk Costello (2002:1-32). McGrath (1999:2) definieer Christelike spiritualiteit soos volg: "Christian spirituality concerns the quest for a fulfilled and authentic Christian existence, involving the bringing together of the fundamental ideas of Christianity and the whole experience of living on the basis of and within the scope of the Christian faith." Vir ' $n$ intensiewe bespreking van die term spiritualiteit, kyk Waaijman (2002).

3 "Spiritualiteit is hier, meer dan de optelsom van een aantal psychologische functies, de fundamentele menselijke capasiteit een ervaring te hebben van en sich te verhouden tot wat in het leven in ultieme zin macht en betekenis heeft" (Tielemann, 19952:124).

4 Die term performance word gebruik in 'n tegniese sin, naamlik as 'n aanduiding van prestasiedruk, stresverwante simptome, uitkomsgebaseerde beroepsprodukte, verwagtingspatrone gekoppel aan professionele beroepe wat hanteer word volgens die eise van globalisering, markkragte en die hedendaagse bestuurskunde (kubernetika en management). 


\section{Die interaktiewe verband tussen geloofsontwikkeling en die verskillende lewensfases}

Dit was veral J.W. Fowler wat gewys het op die verband tussen geloofsontwikkeling en menslike selfverstaan. In 'n fenomenologiese benadering van geloof (Fowler, 1981:32-33) ${ }^{\mathbf{5}}$ kan geloof gesien word as 'n reaksiefenomeen op transendensie. Geloof is dan ten diepste 'n relasionele verskynsel waarbinne bepaalde reaksiepatrone empiries waarneembaar raak. 6

Selfrefleksie beteken onder andere die ontdekking van bepaalde patrone van self-wees wat korreleer met ingewikkelde opeenvolgende ontwikkelingskonstruksies: die sogenaamde psigososiale seisoene van ons lewe (Fowler, 1987:96). Fowler onderskei verskillende fases van selfverstaan en geloof (kyk Fowler, 1987:57; 1981:133 e.v.).

In sy boek Faith development and pastoral care onderskei Fowler (1987:96) ná die fase van "midchildhood" (mities-letterlike geloof) tussen adolessensie dit wil sê die sinteties-konvensionele geloof van die interpersoonlike self, en vroeë adolessensie (fase vier), dit wil sê individuatiewe, reflektiewe geloof en die institusionele self (die self binne die instellings van gesin, skool, kerk en samelewing, met 'n vermoë tot abstraksie en kritiese onderskeiding).

Van belang vir die fase van vroegbejaardheid net voor aftrede is Fowler se beskrywing van fase vyf en ses. Fase vyf noem Fowler die konjunktiewe geloofsfase vanweë die poging om 'n verband te lê tussen die verskillende paradokse van die lewe binne 'n meer volwasse verstaan van sin (adulthood). Die konjunktiewe geloofsfase is 'n poging om vrede te maak met die spanning tussen die verskillende perspektiewe en deelwaarhede soos byvoorbeeld die paradoks dat God sowel immanent as transendent is, geopenbaar is maar tog ook verborge is. In fase vyf word 'n mens bewus van die relatiwiteit van die lewe en dat die verstaan van sin slegs gedeeltelik is.

$5 \quad$ Vir 'n kritiese bespreking van so 'n fenomenologiese benadering tot geloof, kyk Dykstra (1986:45-65).

6 "The patterns of faith that make selfhood possible and sustain our identities are covenantal (triadic) in form" (Fowler, 1981:33). Kyk ook Fowler (1987:55): "To be a self means, at the outset, to be a human being with structuring patterns that shape a distinctive style of being as a person." 
Fase ses beskryf die universalisering- en verbredingstendens in geloof. 7 Gedurende hierdie fase begin geloof om die beperkinge van die tradisie en konvensie te oorstyg in die rigting van 'n meer algemene, geïntegreerde lewensvisie. Dié fase sou goedskiks die fase van verbreding en oorstyging genoem kan word; dit besit 'n verbrede visie van 'n meer universele netwerk en gemeenskap; 'n soort inklusiewe lewensgevoel wat die grense van eksklusiwiteit oorstyg en transendeer.8

Op bladsy 198 van sy boek Stages of faith (1981) verwys Fowler na 'n belangrike faktor tussen die fase van verbinding (konjunksie)/ integrasie en oorstyging (universalisering), naamlik die blootstelling aan 'n intense bewuswording van broosheid en weerloosheid (vulnerability). Dit is hierdie intensiveringsfaktor wat ek graag in dié artikel verder wil bespreek wanneer verwys word na die eise van die knyptangfase tussen prestasiedruk en aftrede - 'n fase wat op die geloof dikwels die impak het van dreinering en eisende oorvraging. Die reserwes van die konjuktiewe fase word gedreineer en "opgebruik", geabsorbeer, om op 'n daaglikse vlak sinvol te voldoen aan die eise van prestasiedruk (performance). Hierdie fase plaas buitengewone druk op singewing en sinneming en behels 'n soort sinabsorbering (die opgebruik van alle sin-reserwes).

Fowler se ontwikkelingsmodel besit beslis waarde vir 'n hermeneutiese benadering van geloofvolwassenheid en geloofsontwikkeling. Alhoewel Fowler se fenomenologiese benadering hipotetiese komponente bevat en dikwels die indruk van 'n kunsmatige, teoretiese konstruksie skep, is dit tog waardevol met die oog op 'n verstaan van die interaktiewe verband tussen geloof en sin.

'n Belangrike gespreksgenoot vir die verstaan van die verband tussen selfverstaan en lewensontwikkeling is Erikson se psigososiale model oor self-ontwikkeling. In sy beskrywing van die lewensiklusse en die uitwerking van sy teorie oor die epigenese van identiteit (kyk Erikson, 1974:91-97; 1978:23-31; 1959:101-145) op menslike selfverstaan en volwassenheid, beskryf Erikson die verskillende psigososiale krisisse waarvoor die mens te staan kom

7 Vir 'n kritiese bespreking van hierdie fase, kyk Parks (1992:99) se Faith development in a changing world.

8 "When asked whom I consider to be representatives of this stage 6 outlook I refer to Gandhi, to Martin Luther King, Jr, in the last years of his life and to Mother Theresa of Calcutta. I am also inclined to point to Dag Hammarskjöld, Dietrich Bonhoeffer, Abraham Heschel and Thomas Merton" (Fowler, 1987:201). 
soos volg: vertroue en wantroue; outonomie versus skaamte en twyfel; inisiatief versus skuld; ywerigheid/arbeidsaamheid versus minderwaardigheid; identiteit versus verwarring; intimiteit versus isolasie; generatiwiteit/produksie versus stagnasie; integriteit versus wanhoop. Alhoewel Erikson hierdie kategoriepare verdeel tussen die verskillende fases, wil ek dit graag sien as 'n weergawe van pole wat eise stel aan die opgawe van singewing en sinneming dwarsdeur die mens se ganse lewe. Volwassenheid op sigself is nooit los van hierdie spanningspole nie. Volwassenheid is inderdaad gekoppel aan die eise wat vertroue, selfstandigheid (outonomiteit), inisitatief (verbeelding), konsensieuse toewyding/arbeidsaamheid, identiteit, intimiteit, generatiwiteit en integriteit aan geloofsontwikkeling stel. Erikson (1978:25) wys daarop dat dit veral gedurende die volwasse fase en die bejaarde fase is dat generatiwiteit bedreig word deur self-absorbering - met daaraan gekoppel die uiters belangrike behoefte aan sorg (care). Daar is ook die bedreiging van oorversadiging ('n soort van walging) wat maklik kan oorslaan in wanhoop. Hieraan koppel hy die faktor van wysheid en onderskeidingsvermoë.

Wat belangrik is vir 'n pastorale hermeneutiek in sowel die modelle van Fowler as dié van Erikson, is die besef dat spiritualiteit nie 'n pasklaar, voltooide saak is nie, maar 'n dinamiese aangeleentheid wat intens verweef is met die verskillende eise wat lewensiklusse aan menslike selfverstaan stel. Hoe hierdie eise gedurende adolessensie en vroeë volwassenheid verwerk word, het 'n belangrike invloed op die latere fases van piekvolwassenheid en bejaardheid. Hierdie feit word onderstreep in die belangrike werk Ageing, spirituality and pastoral care (MacKinlay, 2001). In hierdie bundel opstelle benadruk MacKinlay (2001:112-113) die belang van 'n psigososiale ontwikkelingsmodel vir die verstaan van volwassenheid en verouderingsprosesse. Volgens Vaughn (1994:172) help so 'n ontwikkelingsmodel om 'n verband te lê tussen die narratief van die lewe en die uniekheid van bestaan.

Ontwikkelingsfases beïnvloed beslis die aard en kwaliteit van geloof. Sowel die modelle van Fowler as dié van Erikson onderstreep hierdie feit. Die belangrike vraag is nou: wat is die eiesoortige eise wat die knyptangfase tussen 55 en 65 aan geloofsvolwassenheid en spiritualiteit stel? Hoe beïnvloed prestasiedruk en 'n bewuswording van broosheid die voorbereiding op aftrede en die uiteindelike ontwikkelingstake gedurende die fase van bejaardheid? 


\section{Die knyptangfase van uitmergelende prestasiedruk (performance) en energiesaambundeling (vóór- aftrede)}

Fowler (1981:198) verwys na 'n bewuswording van lewensbroosheid (vulnerability) wat die kwaliteit van selfverstaan direk beïnvloed en bepaal - 'n broosheid wat maklik kan oorslaan in lewensvoosheid. Erikson (1978:25) waarsku teen self-absorbering en walging (disgust). Capps (1993:11) verwys na die impak van prestasiedruk op selfverstaan en beskryf verskynsels soos "the depleted self"; "sin in a narcissistic age" - 'n soort onrealistiese self-inflasie.

Die probleem met volwassenheid gedurende die piekfase tussen 5565 jaar, is dat binne 'n geglobaliseerde, markgedrewe konteks, uitkomste gemeet word aan bestuursmatige topprestasies. Binne so 'n kultuur is pryse, belonings en uitsette dikwels belangriker as die kwaliteit van wéésfunksies. Alles draai om doen- en weetfunksies. So 'n kultuur voed 'n narsissisme wat afhanklik raak van voortdurende prys, flikflooiing en vleitaal. Die skadukant daarvan is 'n inflasie van integriteit, meelewing, empatie en deernisvolle liefde. Pogings om op prestasies te verbeter eindig in verhoogde narsisstiese patologie: “... the repair takes the form of doing more of what they had been doing, even though this was what got them in their current state of vulnerability" (Capps, 1993:27).

Met self-uitputting en self-absorbering word nie bedoel 'n disintegrasie van die self of 'n totale identiteitskrisis nie. Selfuitputting impliseer 'n meer algehele toestand van versadiging wat neig om sensitiwiteit te neutraliseer. 9 Hierdie toestand impliseer 'n toestand van apatie en gedreineerd-wees.

Die besondere druk of knyptang-effek op volwassenheid gedurende die fase tussen 55-65 sluit die volgende aspekte in:

- Die knyptang van singewing: tussen die hoogtepunt van verworwe insig en die intensiteit van afronding

Aan die een kant word 'n hoë premie geplaas op die kwaliteit van kennis- en doenfunksies. Kennis en vaardighede wat oor die jare verwerf is, moet gebruik word om bestaande netwerke uit te bou en kwalitatief te verbeter. In byvoorbeeld professionele en akademiese

9 "For Kohut, self-depletion is a less severe form of self-pathology than selffragmentation, or the disintegration of the self, but it is, for that very reason, a far more common experience and is found among those who appear to be leading productive lives" (Capps, 1993:97). 
beroepe bring die toenemende tendens tot globalisering mee dat veral op internasionale vlak meegeding moet word. Die kompleksiteit van netwerkvorming (networking) bring mee dat die bestaande bronne van kennis en vaardighede getap word. 'n Soort leegsuig-effek kom voor sonder voldoende tyd om die "houer" weer aan te vul.

Aan die ander kant moet voorbereidings vir aftrede getref word. Hierdie situasie bring mee dat onafgehandelde lewenstake afgerond moet word. Een van hierdie take is die taak tot singewing en die uitreik na die pyn van die medemens. Lyding moet geabsorbeer word - daar ontstaan 'n intense besef dat broosheid en pyn 'n wesenlike realiteit van die menslike bestaan is. Die weerloosheid en hulpeloosheid wat lyding teweegbring, moet in hierdie fase as 'n onafwendbare feitelike gegewe geabsorbeer en geïnternaliseer word.

\section{- Die knyptang van beroepsuitsette: tussen effektiwiteit en toepaslikheid}

Om binne die beroepswêreld van professionaliteit te oorleef (soos byvoorbeeld die geneesheer, ingenieur, predikant, sielkundige, maatskappybestuurder) moet mense effektief wees. Teen die laagste koste moet die hoogste mate van effektiwiteit en dienslewering (produksie) ingebou wees. Effektiwiteit beteken dan: kwaliteit van gelewerde diens (produksie) met die oog op verhoogde gebruik (konsumpsie). Mense word kommoditeite waarvan die waarde gemeet word aan die verbruikerswaarde daarvan.

Aan die ander kant is daar die eis van toepaslikheid. Toepaslikheid het te doen met relevansie binne verhoudingsnetwerke en konkrete kontekste. Omdat kontekste teen 'n verbysterende snelheid verander, is die implikasie dat wat vandag toepaslik was, more ontoepaslik is. Nuwe idees en uitvindings veroorsaak dat kennis oornag verouder.

- Die knyptang van ouerskap: tussen die proses van die leëneswerklikheid en geïntensiveerde ouerbetrokkenheidl ouerverantwoordelikheid

Twintig jaar gelede het kinders die huis na matriek verlaat en vir 'n loopbaan voorberei. Sodra die kinders die huis verlaat, was daar 'n vorm van gewaarborgde onafhanklikheid, veral binne gegoede gesinsverbande. Tans bly kinders langer van hulle ouers afhanklik. Hulle trou op 'n later ouderdom en is emosionele sterker aangewys 
op die ondersteuningsnetwerk van die ouerhuis. In armoedeomgewings maak jongmense nog sterker aanspraak op die ondersteuningsnetwerk van die gesin - gesinslede moet mekaar finansieel dra en ondersteun.

Vanweë die feit dat die samelewing meer gefragmenteerd en stresvol raak, word gesinsnetwerke sterker ingespan om lewenseise te hanteer. Die kerngesin word dikwels die stortplek van die emosionele skokke (emosionele afval) wat lede elders in die openbare sektor opdoen. Gevolglik word hoë eise gestel aan die vermoë om konflik binne gesinsverband te hanteer. Die verhoogde egskeidingsyfer bring 'n intensivering van ouerbetrokkenheid mee. Ouers moet nie net die pyn van hulle kinders hanteer nie, maar is dikwels betrokke by die versorging van kleinkinders en hulle probleme. Die vigspandemie dra by tot hierdie nuwe scenario van verlengde ouerbetrokkenheid.

\section{- Die knyptang van verhoudingsdinamika: tussen bejaarde ouers en die subjektiewe voorbereiding op vroegbejaardheid}

Tussen 55-65 jaar is menige volwassene vasgevang tussen die verantwoordelikheid om eie ouers (binne die bejaarde fase) te hanteer of te versorg en om tegelykertyd voorbereidings te tref vir hulle eie aftrede - selfs om voor te berei vir hulle eie broosheid en fisieke probleme. Vanweë inflasie en die inkrimping van aftreefondse bring dit mee dat bejaardes finansieel al hoe meer van hulle kinders afhanklik raak. Die verdere implikasie is dat die kind oor minder fondse beskik om vir sy/haar eie aftrede voorsiening te maak.

- Die knyptang van emosionele, fisieke en verhoudingsgesondheid: tussen die heel-wees van volwassenheid en die broosheid van ouderdom

Die lewensfase 55-65 is 'n belangrike wendingspunt ten opsigte van sowel fisieke kragte as emosionele stabiliteit. Hierdie fase impliseer nie net die bewuswording van eie broosheid en liggaamlike begrensing wat hoë eise aan volwassenheid stel nie. Die verskerpte besef van lyding en dood bring mee dat anders na die lewe en na die konsep "toekoms" gekyk word. Skielik breek die besef deur dat die toekoms in-konsertina met minder beweegruimte na vore. Die lewe lê nie meer oop na vore nie, maar word begrens deur 'n verskerpte besef van eindigheid. 
- Die knyptang van spirituele volwassenheid: tussen geloofsvastigheid (waarheid) en geloofsuitputting, geloofsuitsakking (verslapping)

In 'n vroeër fase het die kerk baie klem geplaas op geloofsekerheid: 'n mens moet seker wees van jou saligheid. Die dringende eis tot saligheid het gegeld. Bekering is op 'n ietwat "godsdienspatologiese wyse" gelykgestel aan sekerheid. $\mathrm{Na}$ ' $\mathrm{n}$ volledige belydenis van sonde is sekerheid verstaan as: Christus het al jou sondes vergewe.

In die fase van piekvolwassenheid gaan dit minder om geloofsekerheid in bogenoemde sin en meer oor geloofsvastigheid. Geloofsvastigheid behels onder andere die vraag na die aard en karakter van waarheid en waaragtigheid. Hoe meer 'n mens bewus raak van relatiwiteit, diversiteit en pluraliteit, hoe minder is jou eksklusiewe verstaan van geloofswaarhede voldoende. In plaas van ortodoksie (die regte geloof met die oog op 'n dogmatiese geloofsverstaan) kom ortopraksie sterker na vore (die regte handeling met die oog op 'n sinvolle of toepaslike geloof). Spiritualiteit verkry 'n soepelheid en beweeg weg van rigiditeit. Dit is natuurlik waar dat indien mense minder emosioneel volwasse is, angs vir verandering en veroudering hulle meer rigied kan laat optree en in fundamentalistiese denkskemas laat dink.

Die uitwerking van bogenoemde pole - ek wil dit miskien eerder dinamiese netwerke noem - is dat daar 'n geweldige suigkrag op sinabsorbering plaasvind. Daarmee word bedoel: 'n uitputting van die fisieke, emosionele en spirituele bronne van persone in hierdie fase. Omdat min aandag in tersaaklike vakliteratuur aan hierdie fase gegee word, is die sosiale en ook kerklike omgewing dikwels onbewus van 'n toestand van gedreineerdheid en apatiese neutraliteit wat ontstaan vanweë verhoogde prestasiedruk. Dikwels is persone in hierdie fase self nie eers bewus van hoe hierdie eksistensiële netwerke hul oriëntasie en fokus op sin beïnvloed nie.

Die verdere probleem gedurende hierdie knyptangfase is ' $n$ verskerpte bewuswording van die uiteindelike take waaraan gedurende die bejaarde fase aandag gegee moet word. Eintlik is die fase tussen 55-65 die fase van voorkomende voorbereiding op die eise van bejaardheid, veral die eise rondom moontlike finale verliese soos byvoorbeeld die verlies aan fisieke gesondheid; onthou- en denkvermoëns (dementia); emosionele kontrole; finansiële agteruitgang; die dood van 'n lewensmaat. 
Watts et al. (2002:143) wys op die belangrikheid van die fase voor aftrede as 'n fase vir veral spirituele ontwikkeling. Verandering en verlies is die twee faktore wat in hierdie fase ' $n$ rol speel.

Research has found that in many cases psychological distress, manifested as agitation and an anxious kind of depression is actually worse in the period leading up to retirement, and people may benefit from pastoral support in advance of the event (Watts et al., 2002:143).

Dit is dan juis die vrees vir verandering en verlies wat aanleiding gee tot 'n neerdrukkende gevoel van loodsware vrees en onsekerheid. Vandaar die besondere uitdaging aan volwassenheid wat volgens Heath (1991:34-35) die volgend insluit: verbeeldingryke simbolisering, 'n gerigtheid op die ander weg van jouself, integrasie, stabiliteit, outonomie en soepel aanpasbaarheid. Volgens McNamara (2002:9) is een van die belangrikste take waarop mense hulleself op bejaardheid moet voorberei, die oorgang vanaf onafhanklikheid na afhanklikheid.

Bejaardheid op sigself is nie 'n "siekte" of "menslike ramp" nie. In 'n sekere sin dui bejaardheid op verdieping, intensiteit en wyse insig oor wat die aard van lewe is. Ouderdom is 'n normale proses. Hierdie besef verander nie die feit dat die liggaamlike afbreekproses buitengewone eise aan die mens se psigiese, emosionele, sosiale en spirituele stabiliteit stel nie.

D.J. Levinson (in Southard, 1989:243) wys op die feit dat bejaardheid dui op verdiepte selfinsig, ' $n$ verbreding ten opsigte van lewensfilosofie en 'n fase van verskerpte integrasie. In 'n neutedop kan gesê word dat bejaardheid impliseer om binne die raamwerk van volwassenheid 'n horisonverbreding van sin, met ander woorde spirituele visionering, te ondergaan. Green et al. (1977:275) wys daarop dat te veel kerkprogramme vir bejaardes net konsentreer op vryetydsbesteding: "... too many church programs deal with merely filling in of time for the elderly or giving them something - card games, recreation, crafts - to help them pass the hours. Human needs, spiritual needs at this time certainly seem to be much deeper than this."

Programme wat gerig is op die voorbereiding van aftrede en die uiteindelike hoog-bejaarde fase (80-100), impliseer die volgende (vgl Louw 1994:164-165): 
- 'n Integrasie van lewenswaardes en norme. Waardes wat geleef is, moet nou hegter gebind en gefokus word op langtermynlewensdoelwitte (kyk Lamb \& Thomson, 2001:57-77).

- 'n Realistiese aanvaarding van lyding, broosheid en afhanklikheid. Die verskerpte werklikheid en bewussyn van siekte en dood omlyn meer as ooit tevore die knyptangfase van aftrede en daarna. Op 'n sinvolle wyse moet vrede gemaak word met lyding, pyn en dood; die teodiseevraagstuk word gevolglik akuut.

- Ego-transendering - met ego-transendering word bedoel 'n oorstyging van 'n identiteit wat bloot gerig is op die vervulling van selfsugtige, individuele, ek-gerigte behoeftes. Spirituele egotransendering beteken dat die ego-differensiasie plaasvind binne 'n verskerpte bewuswording van die ultimate - die X-faktor wat lewe beslissend bepaal (vgl. Lyon, 1985:84).

- Liggaamstransendering. Namate fisieke kragte afneem en mense meer bewus word van die feit dat belangrike fisieke, emosionele en kognitiewe funksies afneem, des te meer moet die "gees" gevoed word. Die voeding van die "gees" impliseer 'n fokusverskuiwing weg van die tydelike en mundane, na die onsigbare dimensie van die bestaan (die sublieme) en die vóór-bewussyn van "ewigheid".

- Die ontwikkeling van soepelheid, aanpasbaarheid en lewenshumor. Humor is die vermoë om binne die cul de sac van lewe 'n nuwe, ander alternatief raak te sien. Paulus is hiervan 'n goeie voorbeeld in 1 Korintiërs 15:55: "Dood, waar is jou angel?"

- Prognostiese denke. Hiermee word bedoel om in die geloof vooruit te gryp op die onvoorspelbare faktor van lewe, naamlik die onkontroleerbaarheid van die toekoms. Prognostiese denke antisipeer nie die noodlot nie, maar in terme van die Christelike hoop en verwagtingskema, die troue liefde en genade van God soos bewys en bevestig in die hoop.

Die Bybel verwys na geloof in die trou van God as 'n verwagtingskema wat ouderdom as "geseënd" bestempel. Ten spyte van die vrees vir isolasie, eensaamheid en verwerping (Ps. 71:18), beteken seën die geloofsbesef dat die lewe 'n ewige dimensie besit wat deurslaggewend bepaal word deur God se troue liefde. "To speak of God's blessing, in other words, is to say that there is an ontological ground to our hope" (Lyon, 1985:12). Prognostiese denke is die konsekwensie van 'n eskatologiese verstaan van lewe, naamlik dat die heil (herskepping) alle aspekte van skepping (ook verganklikheid, dood) deurslaggewend bepaal. Ewigheid is die 
muntkant van verganklikheid. Die ontwikkeling van 'n prognostiese denkskema kan derhalwe deurslaggewend inwerk op die funksionele krisis van bejaardheid, naamlik isolasie, verwerpingsangs en eensaamheid. 10

Wanneer rekening gehou word met die voorafgenoemde ontwikkelingstake met die oog daarop om jouself voor te berei op aftrede en bejaardheid, kan die volgende kernvraag gestel word: watter bydrae kan Christelike geloofsvolwassenheid en spiritualiteit maak met betrekking tot volharding gedurende die knyptangfase tussen 55-65?

\section{Parrhēsia: die stamina van Christelike geloofs- volwassenheid}

In hierdie artikel wil ek pertinent die vraag van 'n teologiese X-faktor aan die orde stel ten einde hermeneuties te bepaal wat die verband is tussen volharding en geloofsvolwassenheid. Myns insiens besit die Nuwe-Testamentiese begrip parrhēsia (volharding, moed, deursettingsvermoë) pastorale implikasies vir die houdingskomponent van geloofsvolwassenheid. Hierdie raaksien van die rol van volharding, moed en deursettingsvermoë bied 'n vastigheid, 'n soort eksistensiële geankerdheid wat kontinuïteit en rigting verskaf.11

In die Nuwe Testament kom die begrip parrhēsia telkens voor.12 In die bediening en optrede van Christus self verwys parrhēsia na 'n openbare outoriteit en gesag (Joh. 7:26; 11:54; 18:20; Mark. 8:22). Hierdie outoritatiewe openbare krag kom duidelik ook na vore in die optrede van die apostels (vgl. Hand. 4:13 en 4:29). Volgens Handelinge $4: 1$ is dit duidelik dat hierdie vorm van openbare oortuigingskrag en kommunikasiestamina nie 'n selfgeproduseerde tipe selfgelding is wat setel in persoonlikheidsvoortreflikheid nie. Hierdie oortuigingskrag beskryf veeleer 'n krag van die Heilige Gees en kan dus as 'n pneumatologiese bestaansfaktor beskryf word. "Hulle is almal met die Heilige Gees vervul en het met vrymoedigheid die Woord van God verkondig" (Hand. 4:31). "Such

10 Oor eensaamheid en die snellerfaktore wat dit verskerp, kyk Freeburg (1981).

11 In sy boek, The courage to be (1952), noem Tillich so 'n bestaansvastigheid die ontologiese faktor wat moed, durf en uithouvermoë verskaf.

12 Dertien keer in die Johannese geskrifte; agt keer by Paulus; vyf keer in die Handelingeboek; vier keer in die Hebreërbrief, een keer in die Markus-evangelie. 
courage is not a human quality; it comes from God (1 Tess. 2:2) and Christ (Ps. 8)" (Hahn, 1976:736).

In 1 Tessalonissense $2: 2$ is dit duidelik dat, anders as by die filosowe van sy tyd wat parrhēsia gesien het as 'n vrymoedigheid wat daarop gerig was om iemand kaalkop die waarheid te vertel ('n soort kommunikasie- en taalvaardigheid om die teëparty wreed te ontmasker en in die openbaar te verneder), Paulus 'n oortuigingskrag beskryf wat van die heilswaarheid getuig. By Paulus verskaf die vrymoedigheid 'n deernis en sensitiwiteit wat 'n besorgdheid (soos 'n verpleegster) en liefde vrystel (1 Tess. 2:7). Hierdie besorgdheid vind neerslag in ' $n$ pastorale houding van empatie en bemoediging (1 Tess. 2:12).

'n Deurslaggewende faktor in parrhēsia is die feit dat parrhēsia slegs moontlik is via die bemiddeling van Christus (kyk Pop, 1964:556). Die vastigheid staan dus in verband met 'n geankerdheid in Christus (1 Joh. 2:28; Heb. 3:6; 10:35) wat alreeds getriomfeer het oor alle magte in die openbare sfeer (Kol. 2:15). In plaas van bestaansangs, verskaf parrhēsia geloofsvertroue en gebedsvrymoedigheid (1 Joh. $5: 14)$. "Thus parrhēsia contains the ideas of 'trust in God, certainty of salvation, the conquest of the consciousness of sin, sanction and power to pray, and expectation of the future"' (Hahn, 1976:737).

In die Hebreërbrief word gewaarsku teen geloofsagteruitgang en verslapping - om terug te deins en moed te verloor (Heb. 10:35, 38). Eksplisiet word in Hebreërs 12:3 gewaarsku dat gelowiges nie geestelik moeg moet word en uitsak nie. En, soos reeds in die artikel beredeneer is, is dit 'n groot faktor wat spirituele moegheid en uitputting (depletedness) tot gevolg het. Dit is egter die verbondenheid met Christus (Ef. 3:12) wat geloofstamina (bestaansmoed) skep en wat kontinuïteit en vastigheid waarborg. "Ons het dus nou deur die bloed van Jesus vrye toegang tot die heiligdom" (Heb. 10:19). Die uitwerking is 'n moment van "styf vashou aan die hoop wat ons bely, want God is getrou: Hy doen wat Hy beloof het" (Heb .10:23).

\section{Slotsom}

By wyse van konklusie kan gesê word dat pastorale terapie wat heling en heelheid (wholeness) verskaf, die oortuigingskrag en uithouvermoë van parrhēsia impliseer - die oortuigingskrag en uithouvermoë wat setel in die X-faktor, die teologiese waarheid van Christelike spiritualiteit. Hierdie X-faktor kan teologies beskryf word as die eskatologiese faktor van ons bestaan. Volgens Bijlsma 
(1978:31) noem ons die X-faktor die eskatologiese dimensie van geloof. "In gewoon Nederlands beteken dit, dat je vertrouwen in God reikt tot over de grens van wat bij mensen mogelijk is." Parrhēsia is pastoraal gesproke daardie vrymoedigheid waarop die geloofsgemeenskap gelowiges moet voorberei in die kerk se uitlewing van koinonia. Gelowiges wat hulle bevind in die knyptangfase tussen prestasiedruk en die weerlose afhanklikheid van bejaardheid, kan deur die geloofsgemeenskap voorberei word om die broosheid van lyding aan te durf met die vergesigte van die hoop.

Hierdie vergesigte van hoop, die periskoop van parrhēsia, kan genoem word die estetiese dimensie van geloofsvertroue: dit "sien" patrone, netwerke en verbande wat midde-in broosheid ook wholeness ontdek. Volgens Umberto Eco in die aangrypende studie oor skoonheid (On beauty: A history of a Western idea) behels die ontdekking van skoonheid die volgende: eenheid te midde van verskeidenheid; 'n verstaan van proporsie en verhouding; die sentiment van verbeelding; die ontdekking van die aanwesigheid van die sublieme (spirituele verhewenheid en adel) binne dit wat belaglik (onsinnig/ridiculous) blyk te wees. "A beautiful thing is defined by the way we apprehend it ..." (Eco, 2004:275). Parrhēsia verskaf 'n andersoortige kyk, 'n estetiese blik op broosheid en weerloosheid (die belaglikheid van die fisieke en emosionele aftakeling van bejaardheid) - dit "sien" - spiritueel gesproke - die hoop in die uitsigloosheid - "The sublime is the echo of a great soul" (Eco, 2004:278).

\section{Geraadpleegde bronne}

ANDERSON, R. 2003. Spiritual caregiving as secular sacrament: A practical theology for professional caregivers. London/New York: Jessica Kingsley.

BIJLSMA, R. 1978. Bijbelse kernwoorden. Kampen: Kok.

CAPPS, D. 1993. The depleted self: Sin in a narcissistic age. Minneapolis: Fortress.

COSTELLO, J. 2002. Introduction: Catholic spirituality. (In Costello, S.J., ed. The search for spirituality: Seven paths within the catholic tradition. Dublin: The Liffey Press. p. 1-32.)

DRISKILL, J.D. 1999. Protestant spiritual exercises: Theology, history and practice. Harrisburg: Morehouse.

DYKSTRA, C. 1986. What is faith? An experiment in the hypothetical mode. (In Dykstra, C. \& Parks, S. Faith development and Fowler. Birmingham: Religious Education Press. p. 45-65.)

ECO, U., ed. 2004. On beauty: A history of a Western idea. London: Secker \& Warburg.

ERIKSON, E.H. 1959. Identity and the life cycle. New York: International Universities Press. 
ERIKSON, E.H. 1974. Identity: Youth and crisis. Second edition. London: Faber \& Faber.

ERIKSON, E.H. 1978. Adulthood. New York: Norton.

FOWLER, J.W. 1981. Stages of faith: The psychology of human development and the quest for meaning. San Francisco: Harper \& Row.

FOWLER, J.W. 1987. Faith development and pastoral care. Philadelphia: Fortress. (Theology and pastoral care series.)

FREEBURG, G.N. 1981. Loneliness: A crisis confronting many of the aged as they approach biological death. Drew University: Microfilms.

GREEN, E. \& SIMMONS, H. 1977. Toward an understanding of religious needs in ageing persons. The Journal of Pastoral Care, 31(4):273-278.

HAHN, H-C. 1976. Parrhesia. (In Brown, C., ed. The new international dictionary of New Testament theology. Exeter: Paternoster. p. 734-737.)

HEATH, H.E. 1991. Fulfilling lives: Paths to maturity and success. San Francisco: Jossey-Bass.

KOURIE, C. 2000. What is Christian spirituality? (In Kourie, C. \& Kretzschmar, L., eds. Christian spirituality in South Africa. Pietermaritzburg: Cluster. p. 9-33.)

LAMB, W.W.H. \& Thompson, H. 2001. Wholeness, dignity and ageing self: A conversation between philosophy and theology. (In MacKinlay, E. et al. Ageing, spirituality and pastoral care. New York: The Haworth Pastoral Press. p. 57-77.)

LOTTER, G. 2001. The so-called 'male mid-life crisis' and marriage. (In Thatcher. A., ed. Celebrating Christian marriage. Edinburgh/New York: Clark. p. 175-185.)

LOUW, D.J. 1994. Illness as crisis and challenge. Halfway House: Orion.

LOUW, D.J. 1999. Pastoraat as vertolking en ontmoeting. Kaapstad: Lux Verbi.

LYON, K.B. 1985. Toward a practical theology of ageing: Theoloy and pastoral care. Philadelphia: Fortress.

MacKINLAY, E. 2001. Understanding the ageing process: A developmental perspective of the psychosocial and spiritual dimensions. (In MacKinlay, E. et al., ed. Ageing, spirituality and pastoral care. New York: The Haworth Pastoral Press. p. 111-123.)

McGRATH, A.E. 1999. Christian spirituality. Oxford: Blackwell.

McNAMARA, L.J. 2002. Theological perspectives on ageing and mental health. (In MacKinlay, E. et al., ed. Mental health and spirituality in later life. New York: The Haworth Pastoral Press. p. 1-15.)

PARKS, S.D. 1992. Faith development in a changing world. (In Astley, J. \& Francis, L., eds. Christian perspectives on faith development. Grand Rapids: Eerdmans. p. 92-107.)

POP, F.J. 1964. Vrijmoedigheid. Bijbelse woorden en hun geheim. 'sGravenhage: Boekencentrum.

SOUTHARD, S. 1989. Theology and therapy: The wisdom of God in a context of friendship. Dallas: Word.

TIELEMAN, D. 1995. Geloofscrisis als gezichtsbedrog: Spiritualiteit en pastoraat in een postmoderne cultuur. Tweede druk. Kampen: Kok.

TILLICH, P. 1952. The courage to be. London: Collins.

VAN'T SPIJKER, W. 1993. Tussen balans. (In Van't Spijker, W., red. Spiritualiteit. Kampen: De Groot Goudriaan. p. 307-330.)

VAUGHN, J.P. 1994. Pastoral care to the ageing: An imaginative response to barrenness. Pastoral Psychology, 42(3):171-184. 
VELEMA, W.H. 1990. Nieuw zicht op gereformeerde spiritualiteit. Kampen: Kok. WAAIJMAN, K. 2002. Spirituality. Leuven: Peeters.

WATTS, F., NYE, R. \& SAVAGE, S. 2002. Psychology for Christian ministry. London/New York: Routledge.

Kernbegrippe:

bejaardesorg

pastoraat en lewensvaardighede

pastorale berading

pastorale hermeneutiek

Key concepts:

pastoral care and counselling

pastoral care to the aged (preventative care)

pastoral hermeneutics

pastoral ministering and life skills 
